\title{
Application of fertility capability classification system in some black soils, red and red laterite soils of Tamil Nadu
}

RAJESHWAR MALAVATH AND S. MANI

Received : 27.05.2014; Accepted : 20.11.2014

\author{
MEMBERS OF RESEARCH FORUM: \\ Corresponding author : \\ RAJESHWAR MALAVATH, Department \\ of Soil Science and Agricultural \\ Chemistry, Acharya N.G. Ranga \\ Agricultural University, HYDERABAD \\ (A.P.) INDIA \\ Email: rajeshoct31naik@gmail.com
}

Co-authors :

S. MANI, Department of Soil Science and Agricultural Chemistry,

Agriculture College and Research Institute (T.N.A.U.), COIMBOTRE

(T. N.) INDIA

\section{Summary}

The study was carried out in the three new research stations of Tamil Nadu Agricultural University with varied soil types viz., Maize Research Station, Vagarai of Dindigul district, Cotton Research Station, Veppanthatai of Perambalur district and Dryland Agricultural Research Station, Chettinad of Sivagangai district of Tamil Nadu were selected for developing the strong soil resource database for proper appraisal of their productivity potential and their rational use. This study was an embodiment with an objective of application of fertility capability classification system in some black soils, red and red laterite soils of Tamil Nadu. Four fertility capability units were identified in the study area. The conditions modifiers identified in the study area were ' $d$ ' dryness, ' $v$ ' high clay content, 'b' basic reaction, 'e' low CEC and 'i' P fixation. The condition modifier 'd' were dominated in its occurrence followed by the condition modifier 'e', 'b' and ' $i$ '.

Key words : Black soil, Soil fertility, Clayey, Loamy and Sandy

How to cite this article : Malavath, Rajeshwar and Mani, S. (2014). Application of fertility capability classification system in some black soils, red and red laterite soils of Tamil Nadu. Asian J. Soil Sci., 9(2): 325-329. 